\title{
The Influence, Gender, Life on Development Planning in Indonesia
}

DESFITRINA

Department of Economy Management Tamansiswa University, Palembang - South Sumatra, Indonesia, E-mail: hertatilesi@yahoo.co.id

\begin{abstract}
The purpose of this study is to determine the position and role of women in the life of the nation and state through national policies carried out by institutions that are able to fight for the realization of gender equality and justice. In order to improve the quality of the role and independence of women's organizations while maintaining the value of unity and unity as well as the historical value of women's struggle in order to continue efforts to empower women as well as the welfare of families and communities. Thus the empowerment of women in the context of realizing gender justice and equality is a commitment of the Indonesian people whose implementation is the responsibility of all parties of the executive, legislative, judicial, religious leaders and society as a whole. The results showed that the role of women greatly affected development. Furthermore, it was found that women could improve the quality of human resources and create gender justice and equality.

Key words Gender, Development Planning

Received: 28 Sept $2018 \quad$ C The Authors 2018

Revised: 24 Oct $2018 \quad$ Published by Human Resource Management Academic Research Society (www.hrmars.com)

Accepted: $\quad 30$ Oct 2018 This article is published under the Creative Commons Attribution (CC BY 4.0) license. Anyone may Published Online: $\quad 3$ Nov 2018 reproduce, distribute, translate and create derivative works of this article (for both commercial and noncommercial purposes), subject to full attribution to the original publication and authors. The full terms of this license may be seen at: http://creativecommons.org/licences/by/4.0/legalcode
\end{abstract}

\section{Introduction}

The empowerment of women continues to be refined its goal is to provide more space for women to actively participate in development (GBHN 1999-2004), establish two-way policies for women's empowerment, namely: First, increasing the position and role of women in national and state life through national policies carried out by institutions that are able to fight for the realization of gender equality and justice. Second, improving the quality of the role and independence of women's organizations while maintaining the value of unity and unity as well as the historical value of women's struggles in order to continue efforts to empower women and the welfare of their families and communities. Thus the empowerment of women in the context of realizing gender justice and equality is a commitment of the Indonesian people whose implementation is the responsibility of all parties of the executive, legislative, judicial, religious leaders and society as a whole. Gender objectives are expected to be a strategy for achieving gender equality and justice through policies and programs that pay attention to experience, aspirations, needs and problems of women and men into the planning, implementation, monitoring and evaluation of all policies and programs in various fields of life and development that ultimately can narrow and even eliminate gender gaps.

In the midst of various national development efforts that have been directed to improve the quality of human resources and create justice and gender equality, inequality is still found in various fields so that women cannot become equal partners and equal to men. One indicator that can be used to measure these gaps are Gender Empowerment Measurement (GEM) and Gender-related Development Index (GDI) which are an integral part of the Human Development Index (HDI), which as a whole is a measure of the quality of human life. 
Based on the Human Development Report 2003, HDI Indonesia ranks 112th out of 175 countries, compared to other ASEAN countries such as HDI Malaysia, Thailand, the Philippines which ranks 59,70 and 77. While the Gender related Development Index (GDI) in 2002 even ranked 91 out of $144 \mathrm{GDI}$ countries are still lagging behind countries in ASEAN such as Malaysia, Thailand, and the Philippines which are ranked 54th, 60th and 63rd respectively (Subhan, 2004). This condition certainly raises concerns, because even though the government has appealed to give more attention to women with a gender mainstreaming strategy but these efforts have not been able to achieve the desired results. Gender bias in government policies at the center and in the regions still occurs due to the low understanding of executive, judicial, legislative decision makers on the meaning, purpose and direction of gender responsive development.

The aim is none other than that all components of government and society are more sensitive and gender responsive to then integrate this concept into planning, implementation and evaluation of public policies made by policy makers at the center and in the regions. The Central Lombok Regency Government, as well as other regions in Indonesia, has responded to the central government's appeal to adopt a gender mainstreaming strategy in policies made by local governments. However, based on observations, this cannot be done by the regional government maximally because this might require a broader and deeper understanding of the concept of gender balance and equality for all stakeholders in Central Lombok Regency. In fact, when viewed from the quality of humans and women in Central Lombok, this gender mainstreaming strategy must be immediately integrated optimally in the planning, implementation and evaluation of all public policies produced by the Central Lombok Regency government.

The Indonesia Human Development Report (IHDR) 2004 reported that the HDI rating of the Central Lombok Regency in 1999 was 287 out of 294 Districts/Cities throughout Indonesia (the eighth lowest). In 2002, although the HDI of the Central Lombok Regency increased, its rank dropped to 338 from 341 Regencies/Cities in Indonesia (the fourth lowest ranking). The quality of women in Central Lombok is not much different from what is described in the HDI, because the numbers are indeed more than half of the population of Central Lombok. The following is a description of the condition of women in Central Lombok, which is shown by GDI (Gender-related Development Index and GEM (Gender Empowerment Measurement) in 1999 and 2002. In 2002 GDI in Central Lombok Regency experienced a slight increase and was no longer included in the District/City ranks with the lowest ranking, this is due to an increase in value in GDI components, in addition because there is a change in the GDI component itself, but when compared with the GDI average in Indonesia which reaches 59.2, the value is still far below the average flat.

There are gaps and inequalities between men and women that are quite striking, especially in the field of education and income. Especially for health, women's life expectancy has increased to 59.2 years, but this figure is still much lower than the average life expectancy of women in Indonesia who can reach the age of 68.1 years. GEM is another indicator that we can use to measure the quality of women's empowerment. The Central Lombok Regency GEM is slightly better than HDI because it is not included in the 10 Regencies/Cities with the lowest GEM. Even so, this condition is not yet encouraging because here the gap between men and women is very evident. This is reflected in the percentage of women who sit in parliament (DPRD), women who hold bureaucracy and leadership positions in private institutions, opportunities in employment and others. The two tables below illustrate the GEM of Central Lombok Regency in 1999 and 2002. Women are still a marginalized group in various ways. Although in terms of obtaining employment, women in Central Lombok get more portions than men, but the work women pursue is not a job that requires high knowledge and skills, but is limited to work that can be done simultaneously with its domestic function. The work that is meant here, for example, works in the handicraft industry, the food industry which in practice can be carried out while caring for children and taking care of household chores.

From the above opinions, it was concluded that the quality of life of women in Central Lombok Regency was still very low, because of the low level of education, health and income. The low quality of women in Central Lombok Regency ideally should be addressed with concrete actions from the local government by planning and implementing development programs and activities that can improve the quality of women. 


\section{Gender}

According to Oakley (1972) in Faqih (1999) gender is a difference that is not biological and not the nature of God, biological differences namely the difference in sex (sex) is the nature of God and therefore permanently different. While gender is a behavioral difference between men and women who are socially constructed, namely differences that are not natural or not God's provisions but are created by humans (men and women) through long social and cultural processes. Based on the two opinions above, concluded that sex and gender are two different things; sex is the sex difference between men and women which is a gift from God and cannot be exchanged, while gender is a concept that separates the roles of men and women which can basically be exchanged and influenced by culture, time, age.

\section{Gender and development}

Julia Cleves Mosse states that gender and development (2003: 2) are fundamentally, gender is different from biological sex. Biological gender is a gift; we are born as a man or woman as gender is a set of roles which, like a costume in a mask in the theater, tell others that we are feminine or masculine; ....... the roles change over time and differ from one culture to another. The role is also strongly influenced by social class, age and ethnic background.

Furthermore, Faqih (1999) stated that gender differences actually did not become a problem as long as they did not give birth to gender inequalities. But the problem is that gender differences have created various injustices, both for men and especially against women. Gender inequality is manifested in various forms of injustice, namely: marginalization or economic impoverishment process, subordination or insignificant assumptions in political decisions, stereotype formation or through negative labeling, violence, a longer and more burdened workload and ideological socialization gender role value.

As a Member of the Fourth World Women's Congress held in Beijing in 1995, Indonesia explicitly accepted the mandate to implement gender into development, meaning that the interests and experiences of women and men become an integral dimension in planning, implementing, monitoring and evaluating policies. policies in development programs and efforts to achieve gender equality and justice. The follow-up was the Government of Indonesia through the 1999 National Guideline, which stated that gender mainstreaming is a national policy that must be carried out by institutions that are able to realize Gender Equality and Justice (KKG). Nevertheless, efforts to achieve the GFC were still experiencing obstacles and were still difficult to be enjoyed by all levels of society in general and especially by women.

The right strategy to be able to reach all government agencies, the private sector, the community and so on. This strategy is known as Gender Mainstreaming (GMS) or Gender Mainstreaming (PUG). This strategy is very important, so the Government considers that it is necessary to issue an Inpres, hereinafter known as the Presidential Instruction No.9 of 2000 concerning Gender Mainstreaming in National Development.

In Presidential Instruction No. 9 of 2000, what is meant by Gender Mainstreaming is a strategy built to integrate gender into an integral dimension of planning, formulating, implementing, monitoring and evaluating national development policies and programs. As for gender equality is the similarity of conditions for men and women to obtain opportunities and rights as human beings, in order to be able to play a role and participate in national political, economic, socio-cultural, defense and security activities, and similarities in enjoying the development results. While gender justice is a process to be fair to men and women.

Soedarti Surbakti said in a journal written on Women in Indonesia; Gender, Equity and Development (2002) says that gender mainstreaming does not only mean integrating gender issues into all aspects of development, but also makes every effort to make development programs more sensitive and gender responsive. In essence, gender mainstreaming is the main strategy to guarantee and ensure that women and men get equal access and opportunities to get development benefits.

Gender mainstreaming is defined by the Economic and Social Council of the United States 1997 (Surbakti; 2002) as the process of assessing implication for women and of all planned actions, including legislation, policies or programs, in all areas and at all levels. It is a strategy of making women as well as men's concerns and experiences an integral dimension of the design, implementation, monitoring and evaluation of policies and programs in all political, economic and social spheres so that women and benefits 
are equally and equality is not perpetuated. (A process for estimating the implications of various planned actions including legislation, policies or programs for men and women. This strategy makes attention to men and women an integral dimension in the planning, implementation, monitoring and evaluation of policies. and programs in the political, economic and social fields so that men and women get the same benefits and imbalances between men and women can be eliminated).

The conclusions that can be drawn from the various opinions are the gender mainstreaming is a strategy to achieve gender justice and equality through policies and programs that pay attention to the experiences, aspirations, needs, problems of women and men in planning, implementing, monitoring and evaluating. This strategy can ultimately guarantee women and men to have equal access and opportunities to control and benefit from development outcomes. The benefits gained from the implementation of gender mainstreaming according to the Ministry of Women's Empowerment are (1) Gaining equal access by men and women to development resources. (2) Participate in the same men and women in the development process, including the decision-making process. (3) Have equal control of men and women over development resources. (4) Obtain the same benefits of men and women from the results of development.

Five stages that can demonstrate the success of gender mainstreaming in national policy according to Marcoes in Surbakti (2002) include: policy planning, formulation, implementation of action plans, policy implementation, monitoring and evaluation. (1) Planning, Formulation and Action. At the planning and policy formulation stage, qualitative and quantitative data on gender differences can be used to identify gender gaps. These data allow decision makers to recognize gender differences in relation to access, participation or opportunities to control and utilize development programs. It is appropriate to analyze the causes of gender gaps and find out the reasons for the failure of gender equality in development policies that ultimately cannot raise the status of women. Furthermore, policies can be formulated again to be more gender responsive. Then followed by an action plan to reduce the gap between men and women. These data then become the main input for gender analysis in the policy formulation stage.

(1) Implementation The implementation of gender responsive policies and programs is highly dependent on local conditions and situations. To ensure that in the implementation of available funds that can meet the needs of men and women in a balanced manner, both must participate in every activity, management and build coordination with stakeholders at all levels.

(2) Monitoring and Evaluation. Differences in gender statistics and indicators are very important to monitor and evaluate gender sensitivity. First, the Evaluator makes a qualitative analysis of a gender sensitive policy or program by testing its contents. Then monitored and evaluated periodically whether there is an increased sensitivity to women compared to men. Second, at the program or project level, monitoring and evaluation can use output indicators, namely how many men and women participate in the program or project. Statistics and indicators derived from sex can be obtained periodically. Third, other things needed are impact indicators to determine whether gender mainstreaming has been effective in narrowing or reducing gender gaps.

In addition to the stages and processes above the Ministry of Women's Empowerment of the Republic of Indonesia also stipulates Minimum Service Standards (SPM) for Women's Empowerment in the Regions as a guideline for the regions to implement women's empowerment in the nuances of regional autonomy. Empowering women in the regions follows the process. District/City authorities in Gender Mainstreaming include the implementation of gender mainstreaming in all development sector activities in the Regency/City. Input required exercising authority. To exercise authority in improving the quality of life of women, especially in the fields of health, education, economics, legal and regulatory protection and the elimination of various forms of violence, input must be owned by the Regency/City. In the context of gender mainstreaming in Central Lombok Regency, the authors limit the discussion of scope related to the quality of life of women which includes aspects of education, health and economics.

\section{Women and Quality of Life}

Female population in almost all regions of Indonesia is larger in number compared to male population, but their quality of life in various fields is still lagging behind compared to men. This can clearly be seen from the Gender Development Index (GDI) which describes the comparison of the quality of life of 
women and men in terms of education, health and income. The Ministry of Women's Empowerment details the concept of women's quality of life in the following three areas:

\section{a. Quality of Life for Women in Education}

Women who are qualified in terms of education can at least finish high school education, but even better if they can continue to higher education. The factors that cause the quality of women are low: 1) The social and cultural value of patriarchy; 2) Young marriage; 3) Forced to take care of domestic work; 4) Must help work; 5) Women's motivation for education is still low; 6) Economic problems; 7) Insufficient understanding of the meaning of education, especially schools. Interventions that need to be done to improve women's education: 1) Provision of scholarships for poor families; 2) Preparation of a more conducive environment for equal access and opportunities for education for girls and boys; 3 ) development of policies that have a gender perspective; 4) gender mainstreaming in the level of participation, curriculum, subject matter, learning process and education actors; 5 ) provision of a social support system for increasing opportunities for girls to attend further education, science and technology education, and vocational education; 6) enhancing women's knowledge regarding the application of appropriate technology with a gender perspective.

\section{b. Quality of Life for Women in Health}

The quality of life of women in the health sector is a condition where women have optimal health conditions in the physical, spiritual and social aspects to improve the next generation. Factors that affect the quality of women's health are: 1) environmental conditions; 2 ) Behavior of the community including women themselves; 3) Health services; 4) Descendants. Women's quality of life needs to be improved by: 1) Empowering communities and women to behave healthily, so that they can maintain, improve and protect their own health and the environment; 2 ) Increase women's access to health services by bringing services to the community closer; 3 ) improving the quality of a healthy environment and utilizing a potential environment to be developed; 4) Facilitating economic empowerment of the poor; 5) Socialization of gender balance and equality; 6) Dissemination of women's health rights.

\section{c. Quality of Life for Women in Economics}

Women's quality of life in the economic field is the readiness of women's motivation, knowledge and ability to take part in economic activities, both micro and small and medium-sized economies. Factors that cause the quality of women in low economic fields are: 1) Lack of women's access to information about the economy and employment; 2) There are stereotypes that place women as domestic workers and men as public workers; 3 ) the dual role of women 4) The existence of laws and regulations that have not been in favor of women; 5) Low education and skills of women; 6) The negative self-concept of women such as the low motivation of women to move forward, the attitude of accepting and surrender, and low self-esteem and apathy.

Interventions needed to improve the quality of life of women in the economic field are: 1) Mainstreaming women's economic productivity in the implementation of the development of the government sector in the economic field; 2) Increased awareness of the company towards increasing women's productivity in the implementation of women's economic empowerment programs; 3) Development of a model for increasing women's productivity at the village level; 4) developing a model for reducing the burden on poor families through alleviation of prime village models; 5 ) Legal protection for women workers; 6) Improving women's resource skills and expertise in the fields of technical production, entrepreneurship, business management and decision making; 7) increase of women in access to information and economic resources; 8) Development of business initiatives conducive to women, among others, non-discriminatory treatment in access to credit, introduction to technology training, and availability of gender-biased regulations.

\section{Development Planning}

Tjokroamidjojo (1995) states that development planning is a process of preparing systematically the activities to be carried out to achieve a particular goal; 2) A way of achieving the best possible goal 
(maximum output) with available resources to be more efficient and effective. Based on the above definition, then Tjokroamidjojo (1995) defines development planning as "A briefing on the use of development resources (including economic resources) that are limited, to achieve the objectives of better socio-economic conditions more effectively and efficiently. Meanwhile Albert Waterston said that development planning is looking forward by taking choices of various alternatives from activities to achieve future goals by continuing to whiz. The main elements contained in development planning according to Tjokroamidjojo (1995) are as follows:

\section{Basic policies or basic strategies for development plans}

Often also referred to as the objectives, direction and priorities of development and includes various development targets. This element is the basis of all plans which are then outlined in other key elements of development planning.

\section{Plan framework}

The second basic element is the existence of a plan framework or also called the macro framework of the plan. In this framework, various development variables (economic) are connected and the implications of these relationships, both social, political and security implications.

\section{Estimated development resources}

Estimates of development resources, especially financing sources are part of the review of the macro framework of the plan. Sources of development financing are strategic limitations in development efforts and thus need to be carefully estimated.

\section{Description of a consistent policy framework}

Various policies need to be formulated and then implemented, one with another development policy must be harmonious and consistent.

\section{Investment program}

The investment program is carried out in a sectoral manner and in its preparation is carried out in conjunction with the preparation of plan goals.

\section{Development administration}

One important aspect in the development planning process is its implementation, and for that it is necessary for a state administration to support the development planning and implementation efforts.

\section{Gender Perspective Development Planning}

Increasing the role of women in development will not achieve optimal results without integrating a gender perspective in all planning activities. Tjokrowinoto (2002) asserts that gender-oriented development planning must try to change the status quo of gender relations that harms women, towards a new equilibrium in gender relations that reflects the principles of harmony, harmony and balance between men and women. Furthermore Moser (IASTP II; 1999) states that gender planning is an approach to address gender issues in projects, programs and planning processes. Gender planning sees that all development planning and programs will have an impact on poor men, women and children. The concept of gender planning encourages development planners to focus on long-term goals and to assess whether a project is oriented towards welfare, efficiency or an empowerment strategy.

The Aus AID's in IASTP II (1999) states that gender planning analyzes development activities based on the dual role of men and women, namely whether the project or program is focused primarily on productive, reproductive, household community service roles or women's political and community management or man. Gender planning also distinguishes between the types of needs resulting from programs and development project planning. Tjokrowinoto (2002) further reminded that several important things in gender-oriented planning are planning (as well as development policies and strategies) is a national/sub-national effort to transform objective-empirical situations of gender relations (das-science) towards normative situations (das-sollens) gender relations as mandated in the GBHN.

In addition to the gender-minded planning process as described earlier, gender analysis (Gender Pathway-GAP Analysis) is a method commonly used to see and find out gender gaps in development 
programs and activities by looking at aspects, access, roles, benefits and controls obtained by men and women. Following is the flow of the Gender Analysis Pathway (GAP):

1) Identification of general objectives of existing project policies and programs.

2) Serve qualitative and quantitative data disaggregated by sex as an opening to insight into how to reveal the impact of different policies and programs on women and men because not all policies and programs have the same impact on men and women.

3) Analyze the causes of the gap. Are these gaps derived from differences in access, control, participation, benefits of development resources.

4) Formulate gender gap issues that occur in step three.

5) Re-formulate the policy/program activity and project steps by considering the gender analysis process carried out, so that it can produce gender responsive activities and projects.

6) Identifying gender indicators and the results of the fifth step formulation.

7) Develop an action plan that can overcome the gap between women and men.

8) Identification of program/project activity targets.

9) Evaluation and monitoring to determine the extent to which policies and programs have been implemented. (Ministry of PP: 2001).

The Gender Analisys Pathway Method (GAP) above can contribute ideas in establishing development programs and increasing the insight of the importance of effectiveness and efficiency and the feasibility of development planning that always takes into account the interests of women and men.

From the description above, the author will try to make a simple concept of development planning with a gender perspective and measurements that can be used to find out its success. As before, the authors limit the discussion of development planning with a gender perspective on aspects of improving the quality of life of women, in this case concerning planning in the fields of education, health and economics, so that the indicators that the authors use to assess planning performance are the achievements of these three sectors in development planning activities.

The theory and opinion above lead the writer to make a conclusion that the core of planning with a gender perspective is integrating the problem of discrimination against men and women into all components/elements of development planning. So that the interests, aspirations and needs of increasing the role and participation of women and men in development can be accommodated proportionally to the interests and objectives of the development of sector institutions. In order to examine the results of the planning carried out by development planners in Central Lombok Regency, especially those relating to improving the quality of life of women, the authors limit the elements or variables to be studied are the results of the implementation of gender mainstreaming policies in development planning.

Factors affecting gender mainstreaming in development planning. Tjokrowinoto (2002) proposes several things that are needed as a requirement for implementing a gender perspective planning, namely, the existence of political will, the existence of institutions in the structural context that can carry out gender responsive plan; While the Ministry of Women's Empowerment put forward several factors that influence the planning process and results of gender perspective, namely decision makers, planners, data and information, indicators, instrument tools, target groups.

In addition to the two opinions above, the author feels the need to consider the opinion of Murniati (2004: 75) which says that "the relationship between women and men in Indonesia is still dominated by gender ideology that produces patriarchal culture". Still according to Murniati (2004) "Patriarchal roots in Indonesia are sourced from various aspects, namely: (sociological) division of labor and and function in society, (culture) feudalism and religious teachings, traditions or customs, (politics) colonialism, imprealism, and militarism, (economic) capitalism. Whereas according to Mosse (2003) states that the concept of men holds power over all important roles in society - in government, military, education, industry, business, health care, advertising, religion - and that women are uprooted from access to that power. This does not necessarily mean that women have no power at all, or have absolutely no rights, influence and resources; rather the balance of power actually benefits men.

The relevance of the behavior of the bureaucratic apparatus in this case the development planner in planning also cannot be separated from the attachment to the cultural values that develop in the local community. Bureaucratic culture that develops in a particular area cannot be separated from the cultural 
patterns of the social environment that surrounds it. Dwiyanto et al. (2002) stated that culture can be described as a system or set of values that have symbols, value orientation, beliefs, knowledge and experiences of life internalized into the mind. This set of values is actualized into attitudes, behavior, and actions carried out by each bureaucratic apparatus. Every aspect of the life of the bureaucratic organization always intersects with the cultural aspects of the local community. Bureaucracy like other organizations, in every dynamic that occurs within it, always has a correlation with the external environment".

From some of these opinions, it was concluded that the factors that might influence gender mainstreaming in development planning in Central Lombok Regency were the Commitment of leaders, Planners, Local Culture. Data and information that supports the planning process. Furthermore, these factors can be explained as follows, Commitment is defined as an attachment to doing something. Understanding of the concepts, objectives and principles of gender mainstreaming influences leadership commitment and ultimately influences the success of gender mainstreaming in development planning. Without the support and commitment of top management, an organization's main focus may be on other activities. In the context of public organizations, the leader's perception of gender balance and equality influences the policies made because in the government bureaucracy it is undeniable that various existing policies and rules will become references in carrying out an activity. Thus the leadership perception that supports gender mainstreaming in development planning is not enough to improve the quality of planning for the improvement of women's quality of life, but the leadership's perception must be formulated in the form of policies that lead to emphases that can be a driving force in realizing a gender perspective development planning. Development planners are government officials who carry out development planning activities and processes. From the state apparatus and/or government apparatus, it is expected or demanded the existence of good ability in the form of knowledge, skills and attitudes that are adequate, in accordance with the demands of current service and development (Handayaningrat, 1986).

Munir (2002) states that to achieve good development planning results, human factors have an important and strategic role. This means that it is necessary to pay attention to that is doing the planning. In this connection the important thing is that every development planner must do what is his duty. In addition to the two opinions above, Mosse (2003) states that women's access to power is often smaller than men's access from. The local culture is a cultural value system adopted by the people who inhabit a particular area. The process and results of development planning with a gender perspective are also determined by the planners' awareness, insight and commitment to the vision of gender equality and justice, gender gaps and efforts to solve them. Besides that, mastery of methodology and planning tools/techniques will also support the process and results of planning. The quality of women in development is still very low (Hertati, 2016), which causes the role of women to be left behind in everything. So to overcome this, we need efforts and strategies to integrate gender into the flow of development by placing women as the subject of development and eliminating the constraints faced by women in development by conducting an analysis and evaluation of the extent to which women are involved in development programs (Hertati, 2015).

The population of Central Lombok Regency, which is dominated by the Sasak tribe, adheres to the Sasak culture which upholds the value of patriarchal culture. This culture does not accommodate equality, balance, so women are not important to be taken into account. Furthermore, patriarchal culture is generally defined by Murniati (2004: 81 ) as a system characterized by men (fathers). In this system, men in power to determine. Because the position of women is determined to be lower than men. The role of women who are used develops into women's empowerment which means improving the quality and role of women in all aspects of life either directly or indirectly (Hertati, 2015). Data is information or information about something that in planning is considered as a basis for being able to make considerations in determining goals and policies. (Sitanggang: 1999;). Data and information on gender issues that are complete, objective and factual will help planners to provide clarity on gender issues and their potential and resources for solving them.

\section{Conclusions}

Integration of gender aspects in the development planning process so as to produce a gender responsive development plan cannot yet be realized. Planning results conducted so far indicate that gender 
responsive planning to improve women's quality of life can be realized. Many factors led to this and ultimately hampered the realization of gender mainstreaming in development planning. The low level of understanding and insight of planners about gender mainstreaming in development planning causes sensitivity to design programs and activities that can improve the quality of life of women to be small. The patriarchal local culture that develops in Sasak society dominates the organizational culture in Central Lombok Regency so that the mindset of bureaucrats and development planners is still influenced by the existing local culture. As a result, planning programs and activities does not become a necessity for planners to pay attention to the sense of justice for women and men.

\section{References}

1. Arikunto, S. (2002). Research Procedure, Rineka Cipta, Jakarta.

2. BPS, Bappenas and UNDP (2004). Indonesia Human Development Report 2004: The Economics of Democracy - Financing Human Development in Indonesia, BPS, Bappenas and UNDP, Jakarta.

3. Dwiyanto, Agus et al. (2002). Reform of Public Bureaucracy in Indonesia, Center for Population and Policy Studies UGM, Yogyakarta.

4. Faqih, M. (1996). Gender Analysis, Student Library, Yogyakarta.

5. Handayani, T. and Sugiarti (2002). Gender Research Concepts and Techniques, Muhammadiyah University, Malang

6. Hertati, L. (2015). Internal Control and Ethics of Quality Management System Accounting Information and Implications on the Quality of Accounting Information Management: Proposing a Research Framework. International Journal of Economics, Commerce and Management United Kingdom Vol. III, Issue 6, June 2015 Licensed under Creative Common Page 902 http://ijecm.co.uk/ISSN 23480386.

7. Hertati, L. (2015). Research Article Total Quality Management as Technics on Strategic Management Accounting. International Journal of Recent Advances in Multidisciplinary Research. Vol. 02, Issue 11, pp.0942-0949, November.

8. Hertati, L. (2016). Just In Time, Value Chain, Total Quality Management, Part Of Technical Strategic Management Accounting. International Journal Of Scientific \& Technology Research Volume 5, Issue 04, April 2016 ISSN 2277-8616.

9. Hertati, L. (2015). Competence of Human Resources, the Benefits of Information Technology on Value of Financial Reporting in Indonesia. Research Journal of Finance and Accounting www.iiste.org.ISSN 2222-1697 (Paper) ISSN 2222-2847 (Online) Vol.6, No.8, 2015.

10. Hertati, L. (2015). Impact Of Uncertainty Of Environment And Organizational Cultural On Accounting Information System Management And Implications For Managerial Performance Proposing A Conceptual Framework. International Journal of Economics, Commerce and Management United Kingdom Vol. III, Issue 12, December 2015.Licensed under Creative Common Page 455 http://ijecm.co.uk/ ISSN 2348 0386.

11. Marcoes, Lies et al. (2001). Gender and Development, Ministry of PP RI can CIDA

12. Marcoes, Lies et al. (2001). Gender Mainstreaming A Strategy in Development, Ministry of PP RI can CIDA.

13. Marcoes, Lies et al. (2001). Guide to Gender Mainstreaming in Development, Ministry of PP RI can CIDA

14.Marcoes, Lies et al. (2001). Case Study of the Use of Gender Analysis in Selected Sectors, Ministry of PP RI can CIDA

15.Mas'ud, M. (2004). Lecture Module on Political Economy Development

16.Moloeng, L. J. (2002). Qualitative Research Methodology, Teens Rosdakarya, Bandung

17.Mosse, J. C. (2003). Gender and Development, Student Library, Yogyakarta

18. Munir, B. (2002). Regional Development Planning: Perspective of Regional Autonomy, Bappeda of NTB Province, Mataram.

19.Murniati, A., Nunuk. P. (2004). Vibrate Gender: Indonesian Women in Religion, Culture and Family Perspectives, Indonesia, Sumatra, Magelang.

20.Narbuko, C., Ahmadi, A. (2001). Research Methodology, Bumi Aksara, Jakarta. 
21.Riyadi (2004). Regional Development Planning, Gramedia, Jakarta.

22.Singarimbun, M., Effendi, S. (1995). Survey Research Methods, LP3ES, Jakarta.

23.Sugiyono (2003). Administrative Research Method, Alfabeta, Bandung

24.Sitanggang, H. (1999). Development Planning, Library of Sinar Harapan, Learning.

25.Tjokrowinoto, M. (2002). Development, Dilemma and Challenges, Student Library, Yogyakarta.

26.Tjokroamidjojo, B. (1995). Development Planning, Toko Agung, Jakarta.

27.Todaro, M. P. (1995). Economics for Developing Countries, Bumi Aksara, Jakarta.

28. Republic of Indonesia (2000). Presidential Instruction Number 9 of 2000 concerning Gender Mainstreaming.

29.State Ministry of Women's Empowerment Office (2002). Decree of the State Minister for Women's Empowerment Number 23/SK/Meneg.PP/VI/2001 concerning Guidelines for Establishing Minimum Service Standards for SPM for Empowering Women in Provinces, Districts/Cities as Autonomous Regions.

30.Office of the State Minister for Women's Empowerment (2002). Minimum Service Standards (SPM) Empowering Women in the Regions.

31.Indonesian Ministry of Women's Empowerment (2002). Guidelines for Implementation of Presidential Instruction Number 9 of 2000 concerning Gender Mainstreaming in National Development

32.Republic of Indonesia Ministry of Women's Empowerment (2002). Gender Perspective Planning Guide.

33.Office of the State Minister for Women's Empowerment (2002). Women's Quality and Violence against Women.

34.Minister of Home Affairs of the Republic of Indonesia (2003). Decree of the Minister of Home Affairs No. 132 of 2003 concerning General Guidelines for Implementing Gender Mainstreaming in Regional Development.

35.Central Lombok Regency Government, Central Lombok District Strategic Plan 2001-2005.

36.Central Lombok Regency Government, Regional Budget (APBD) 2003, 2004 and 2005.

37.Central Lombok Regency Government, General Policy Direction (AKU) in 2003, 2004 and 2005.

38.Central Lombok Regency Government, 2005 Local Government Work Plan (RKPD).

39.BPS Central Lombok Regency, Central Lombok In 2004 Figures. 